\title{
Macro and trace mineral content of selected south Texas deer forages
}

THOMAS G. BARNES, LARRY W. VARNER, LYTLE H. BLANKENSHIP, THOMAS J. FILLINGER, AND SHARON C. HEINEMAN

\section{Abstract}

White-tailed deer (Odocoileus virginianus) derive the majority of their dietary mineral intake from range forages which may be deficient in one or more essential minerals. We have described the macro and trace mineral concentration of 18 shrub, 26 forb, 7 grass, and 1 cactus species, known to occur in south Texas deer diets, collected from the Chaparral Wildife Management Area in 1974 and 1975. Within each forage class, there were no seasonal differences in calcium (Ca), sodium (Na), potassium (K), or magnesium $(\mathrm{Mg})$ concentrations. Phosphorus $(P)$ concentrations in browse were higher $(P \leq 0.05)$ during the spring $(0.20 \%)$ then during other seasons $(0.14-0.16 \%)$. Forb $P$ concentrations were greatest during the spring and winter periods $(0.26$ and $0.29 \%$, respectively), and $P$ levels in grasses $(0.24-0.14 \%)$ decreased as the forage matured and reached senescence. Shrubs contained less $P$ and $K$ $(P \leq 0.01)$ than either grasses or forbs; whereas, grasses contained lower concentrations of $\mathrm{Ca}$ and $\mathrm{Mg}(P \leq 0.01)$ than shrubs or forbs. Sodium concentrations did not differ among forage classes. Forbs contained greater $(P \leq 0.01)$ levels of copper $(\mathrm{Cu})$ and zinc $(\mathrm{Zn})$ than grasses or browse, and browge contained less iron (Fe) $(P \leq 0.01)$ than forbs or grasses. Manganese concentrations did not differ among forage classes. There were differences in mineral concentrations among species within forage class. Results suggest concentrations of all minerals except $P$ met or exceeded minimum domestic animal requirements. Managers should provide a diversity of plant species and encourage practices that promote forb growth to provide optimum and nutritional benefits for deer.

Key Words: calcium, copper, iron magnesium, manganese, phosphorus, potassium, sodium, zinc, white-tailed deer, Odocoileus virginianus, south Texas

Habitat carrying capacity is constrained largely by forage availability and quality, which varies between species spatially and temporally within species. Deer derive the bulk of their dietary mineral intake from range forages which may be deficient in one or more essential minerals. For exâmple, $P$ levels in browsô, â stâplè in south Texas deer diets during all seasons of the year (Varner and Blankenship 1987), is greatest during periods of active growth and then declines rapidly and levels off as senescence is approached (Jones and Weeks 1985). Even during periods of active growth, $P$ levels may not meet suggested animal requirements in the vegetation in south Texas (Meyer and Brown 1985). The availability problem may be exacerbated in browse because absorbtion of $P$ may be incomplete (Barnes 1988). In addition to deficiency problems, many trace minerals (I, $\mathrm{Cu}_{\mathbf{u}}, \mathbf{Z}_{\mathbf{n}}, \mathbf{S e}$ ) may be toxic tô wildifie ât elevated levels (Robbins 1983).

Authors were graduate research assistant, Department of Wildlife and Fisheries Sciences, Texas A\&M University, College Station 77843; research scientists, Texas Agricultural Experiment Station, 1619 Garner Field Road, Uvalde 78801; and research assistants, Texas Agricultural Experiment Station, 1619 Garner Field Road, Uvalde 78801. Current address of Barnes is Department of Forestry, University of Kentucky, Lexington 40546-0073. Current address of Varner is \#11 Donna Drive, Uvalde, Texas 78901. Current address of Dlankeñshitip is Dox 5220 , Uvalúe, Texas 78802. Current addresses of Fillinger and Heineman are Box 362, D'Hanis, Texas 78850 , and Route 1, Box 48 , Knippa, Texas 78870 , respectively.

Research was funded by the Caesar Kleberg program in Wildlife Fcology at Texas A\&M University and the Texas Agricultural Experiment Station. We extend sincere appreciation to the staff at the Chaparral Wildlife Management Area, Texas Parks and Wildlife Department for their cooperation during this study. Authors wish to thank C. Hensarling for technical assistance and M.M. Kothmann, W.C. Greene, P.J. Kalisz and anonymous reviewers for critical review of this manuscript.

Manuscript accepted 27 July 1989.
The nutritional quality of Texas range plants follows plant growth patterns. The peak generally occurs during spring when growth is most active and levels decline steadily reaching the lowest levels during winter (Huston et al. 1981). However, during years with abundant moisture coupled with mild winter temperatures, forage quality follows a bimodal pattern with peaks in quality occurring during the spring and winter (Varner et al. 1977). Most previous research has focused primarily on quantifying in vitro digestibility, crude protein, and energy content of deer forages. Limited quantitative information is available on seasonal dynamics of macrominerals (Greene et al. 1987) or trace minerals (Nuwanyakpa et al. 1983, Staaland et al. 1983) of range plants, especially deer forages (Everitt and Gonzalez 1979, Jones and Weeks 1985). The majority of studies have focused on grasses or domestic livestock forages and have examined only a small number of minerals and plant species. To complement previous studies on food habits, proximate nutrient composition and in vitro dry matter digestibility (Varner et al. 1977, Varner and Blankenship 1987), we investigated live tissue changes in $\mathrm{P}, \mathrm{Ca}, \mathrm{Mg}, \mathrm{Na}, \mathrm{K}, \mathrm{Cu}, \mathrm{Fe}, \mathrm{Mn}$, and $\mathrm{Zn}$ concentrations of 18 browse, 26 forb, 7 grass, and 1 cactus species known to occur in south Texas deer diets.

\section{Study Area and Methods}

Forage samples were collected on the 6,073 ha Chaparral Wildlife Management area located in Dimmitt and LaSalle counties of the south Texas Acacia, Condalia, Prosopis thorn scrub savanna. The regional climate is moderate, characterized by hot, dry summers and short, mild winters with an annual mean temperature of $22^{\circ} \mathrm{C}$. Annual precipitation falls in a bimodal pattern with peaks in the spring and fall. During the 30-yr period 1932-1962, annual rainfall ranged from 45.7 to $76.2 \mathrm{~cm}$ (USDA 1976). During the 8 years preceding this study, it ranged from 50 to $117 \mathrm{~cm}$ and averaged $75 \mathrm{~cm}$ (Lynch 1977). Mean annual rainfall during the collection period was $76.0 \mathrm{~cm}$.

Eight soil types and 6 range sites are present in the study area, but most of the area is composed of Duval Fine Sandy Loam series soils. The study area has a history of light to maderate grazing pressure ( 8 to $16 \mathrm{ha} /$ animal unit) and is considered to be in good range condition as measured by Lynch (1977).

The dietary importance of forage species sampled was determined from published studies (Chamrad and Box 1968, Everitt 1972) and laboratory examination of rumen contents from sacrificed deer on the Chaparral area. Samples were collected in May, Jüne, añd October 1974 and January, Âpril, and Jüly 1975. Because animals forage selectively, care was taken to collect only new growth $(P \leq 3 \mathrm{~cm})$ to simulate browsing patterns of whitetailed deer. A minimum of 10 individual plants of each species growing within a 3-m radius circle were clipped and composited to reduce interplant variability. Plant phenology dictated that some species could not be collected during every season and were collected as available.

Composite samples were oven-dried at $60^{\circ} \mathrm{C}$, ground through a 2-mm screen in a Wiley mill, mixed, and stored in air-tight containers. These samples were wet digested or dry ashed at $500^{\circ} \mathrm{C}$ for 8 hours and diluted with deionized water. Phosphorus was deter- 
mined calorimetrically on the wet digested samples (Kallner 1975). Concentrations of remaining minerals were quantified using atomic absorption spectrophotometry. All samples were run in duplicate and results were averaged. Results are presented on an ash-free dry mass basis.

Analysis of variance and LSD (least significant differences) tests were used to detect differences $(\boldsymbol{P} \leq 0.01)$ in mineral concentrations among forage classes (browse, forb, grass). Analysis of variance and LSD were also used to determine species and seasonal differences $(P \leq 0.05)$ within each forage class. Only species represented by a minimum of 3 collection periods were included for statistical analysis.

\section{Results}

Concentrations of $\mathrm{Ca}, \mathrm{Na}, \mathrm{K}, \mathrm{Mg}, \mathrm{Zn}, \mathrm{Cu}$, and $\mathrm{Mn}$ did not vary seasonally within forage classes; therefore, these data were pooled to make individual species within class comparisons (Table 1). Forbs contained lower levels of Fe during the fall than at other seasons. There was no seasonal difference in Fe content in grasses or browse.

Phosphorus content in grasses, forbs, and browse was seasonally variable (Table 2). Phosphorus levels in browse were higher during spring, then dropped and remained static for the remainder of the year. Phosphorus levels also varied as a function of forage class. Browse contained less $P$ than non-browse species (Table 2).

Remaining macrominerals also varied as a function of forage class. Browse contained less $\mathrm{K}$ than non-browse species; $\mathrm{Ca}$ and $\mathrm{Mg}$ content in grasses was lower than in browse or forbs. Sodium concentrations did not differ among forage classes. Concentrations of trace minerals, except $\mathrm{Mn}$, differed among forage classes (Table 1). Forbs contained greater concentrations of $\mathrm{Cu}$ and $\mathrm{Zn}$ than nonforb species, and shrubs contained less $\mathrm{Fe}$ than either grass or forbs. This may be a function of soil contamination on low growing herbaceous forages.

There was substantial variation among species and within species by season. For example, $P$ concentration ranged from a low of $0.14 \%$ in Linum rigidum in the summer to $0.28 \%$ in the spring. In addition, $P$ content within forb species varied from $0.14 \%$ in Linum rigidum to $0.38 \%$ in Gaillardia pulchella and Heterotheca subaxillaris. Mineral content in grasses did not vary as strongly as in forbs, browse, or cacti within a species or by season. Chloris cucullata was an exception exhibiting lower $\mathrm{P}, \mathrm{Mg}$, and $\mathrm{Cu}$ values than other grass species. Prickly pear cactus had higher levels of $K$, $\mathrm{Mg}, \mathrm{Zn}$, and $\mathrm{Mn}$ than other species during all seasons.

\section{Discussion}

The lack of seasonal differences in mineral concentrations is not surprising since care was taken to collect only current year's
Table 2. Seasonal variation in the phosphorus concentrations $(\%$ of $\mathrm{dr}$ matter) of browse, forbs, and grass collected from 2 range sites on the Chaparral Wildlife Management Area, south Texas during 1974 and 1975.

\begin{tabular}{lcccc}
\hline \hline & & \multicolumn{2}{c}{ Season } & \\
Group & Spring & Summer & Fall & Winter \\
\hline Browse & $0.20 \mathrm{~A}^{1}$ & $0.15 \mathrm{~B}$ & $0.16 \mathrm{~B}$ & $0.14 \mathrm{~B}$ \\
Forb & $0.26 \mathrm{BC}$ & $0.20 \mathrm{~A}$ & $0.22 \mathrm{AB}$ & $0.29 \mathrm{C}$ \\
Grass & $0.23 \mathrm{BC}$ & $0.24 \mathrm{C}$ & $0.19 \mathrm{AB}$ & $0.14 \mathrm{~A}$ \\
\hline
\end{tabular}

Values in rows followed by different letters are significantly $(P<0.05)$ different.

growth, simulating deer browsing. This may have biased the results because deer will consume dead tissue; however, deer usually select live tissue growing on stems less than $2.1 \mathrm{~mm}$ in diameter if it is available (Shafer 1963). Collection methods then are critical because animals forage selectively seeking live vs. dead tissue and leaf vs. stem material (Poppi et al. 1981, Stuth et al. 1986) with concomitant differences in mineral concentrations (Greene et al. 1987).

Ultimately, moisture, temperature, and soil nutrients are the environmental factors which will affect plant growth and nutritive value. Precipitation during the study was high $(76 . \mathrm{cm})$ and had been at this level during the preceding 8 years. In addition, precipitation fell during every month of the study which, coupled with moderate temperatures, allowed the vegetation to grow actively during every collection period. Soil nutrients are the final environmental variable and appear adequate for all minerals except $P$ which is deficient in south Texas (Fisher 1974).

Phosphorus requirements for deer are not well delineated but early studies indicated between 0.25 and $0.56 \% \mathrm{P}$ is required for optimum growth and development of white-tailed deer (Magruder et al. 1957, McEwen et al. 1957). These estimates are above those for domestic livestock (0.16-0.18\%). Barnes (1988) observed that white-tailed deer in south Texas absorbed only one half of total $P$ when provided access to a diet containing $0.56 \% \mathrm{P}$ and demonstrated no apparent deficiency problems. This result agrees with Ullrey et al. (1975) that weaned white-tailed deer fawns require no more than $0.26 \% \mathrm{P}$ in the diet. Based upon this information, forbs appear to provide an adequate source of $P$ during most seasons, and food habits data indicate they constitute a high percentage of the diet whenever available (Chamrad and Box 1968, Kie et al. 1980).

Browse appears to contain marginally adequate $\mathbf{P}$ only during the spring, and grasses are deficient in the fall and winter. Forb growth in south Texas is highly dependent on adequate moisture and mild temperatures. During drought and hot, dry summers, deer switch to a largely browse diet (up to $97 \%$ of their diet, Varner

Table 1. Macro and trace mineral concentration (ash free dry matter basis) of forbs, browse, grass and cacti collected in 1974, 1975 from 2 range sites on the Chaparral Wildlife Management Area, south Texas.

\begin{tabular}{|c|c|c|c|c|c|c|c|c|c|c|c|c|}
\hline \multirow[b]{3}{*}{ Mineral } & \multirow[b]{3}{*}{$\bar{X}$} & \multicolumn{10}{|c|}{ Group } & \\
\hline & & \multicolumn{2}{|r|}{ Forb } & \multicolumn{3}{|c|}{ Browse } & \multicolumn{3}{|c|}{ Grass } & \multicolumn{3}{|c|}{ Cacti } \\
\hline & & SD & Range & $\bar{X}$ & SD & Range & $\bar{X}$ & SD & Range & $\overline{\boldsymbol{X}}$ & SD & Range \\
\hline Phosphorus (\%) & $0.24 \mathrm{~B}^{1}$ & 0.06 & $0.17-0.38$ & $0.16 \mathrm{~A}$ & 0.06 & $0.07-0.38$ & $0.21 \mathrm{~B}$ & 0.05 & $0.08-0.28$ & 0.15 & 0.04 & $0.10-0.20$ \\
\hline Calcium (\%) & $1.65 \mathrm{~B}$ & 0.66 & $0.61-3.55$ & $1.91 \mathrm{~B}$ & 1.37 & $0.13-6.03$ & $0.32 \mathrm{~A}$ & 0.08 & $0.17-0.57$ & 2.99 & 0.86 & $1.85-5.21$ \\
\hline Sodium $(\%)$ & $0.41 \mathrm{~A}$ & 0.20 & $0.10-1.10$ & $0.36 \mathrm{~A}$ & 0.16 & $0.10-1.10$ & $0.43 \mathrm{~A}$ & 0.26 & $0.10-1.00$ & 0.45 & 0.15 & $0.30-0.60$ \\
\hline Potassium (\%) & $2.48 \mathrm{~B}$ & 1.22 & $0.92-5.20$ & $1.41 \mathrm{~A}$ & 0.55 & $0.07-3.47$ & $2.71 \mathrm{~B}$ & 1.10 & $0.83-5.96$ & 3.63 & 1.16 & $1.87-4.83$ \\
\hline Magnesium (\%) & $0.32 \mathrm{~B}$ & 0.18 & $0.17-1.12$ & $0.36 \mathrm{~B}$ & 0.18 & $0.11-0.80$ & $0.17 \mathrm{~A}$ & 0.04 & $0.09-0.22$ & 1.21 & 0.20 & $0.91-1.47$ \\
\hline Zinc (PPM) & 48.7C & 20.6 & 24-111 & $25.4 \mathrm{~A}$ & 14.7 & $11-76$ & $38.3 B$ & 14.4 & $13-60$ & 23 & 6.2 & $15-32$ \\
\hline Copper (PPM) & $8.6 \mathrm{C}$ & 2.7 & $2.9-17.0$ & $6.6 \mathrm{~B}$ & 2.6 & $2.4-15.4$ & $4.5 \mathrm{~A}$ & 1.4 & $1.8-7.1$ & & - & \\
\hline Iron (PPM) & $123.0 \mathrm{~B}$ & 23.6 & $49-230$ & $83.4 \mathrm{~A}$ & 42.5 & $26-154$ & $116.3 \mathrm{~B}$ & 46.0 & $59-219$ & 81 & 18.8 & $64-113$ \\
\hline Manganese (PPM) & $49.0 \mathrm{~A}$ & 30.6 & $15-166$ & $38.0 \mathrm{~A}$ & 168 & 15.107 & $45.8 \mathrm{~A}$ & 16.1 & $27-103$ & 291 & 131.6 & $152-501$ \\
\hline
\end{tabular}

'Means within rows followed by different letters are significantly $(P \leq 0.01)$ different. Cacti were not included in statistical tests due to insufficient sample sizes. 
and Blankenship 1987) which appears deficient in P during much of the year. In addition, $P$ in browse may not be readily available since browse is highly lignified and contains secondary plant compounds which may interfere with absorption (Barnes 1988).

Deer are probably adapted morphologically, physiologically, and behaviorally to chronic recurring mineral deficiencies (Weeks and Kirkpatrick 1976) and select high $P$ containing forbs ( $\mathrm{Ambro-}$ sia psilostachya, $0.32 \%$ and Euphorbia spp. $0.30 \%$ ) whenever available (Kie et al. 1980). Dietary P intake appears to be at its highest during the spring when $P$ content of forbs is high and they contribute $>50 \%$ to the deer's diet (Arnold and Drawe 1979). Deer may have a mechanism for conserving and transferring $P$ from skeletal bone to antlers in a manner similar to known mechanisms of Ca transfer (Stephenson and Brown 1984). Such a mechanism would allow them to select high $\mathbf{P}$ forbs in the spring and conserve $P$ during stress periods. Deer may also obtain $P$ by visiting mineral licks (Weeks and Kirkpatrick 1976) and through osteophagia (Krausman and Bissonette 1977) although soil P levels are also deficient in south Texas (Fisher 1974). However, if $P$ requirements of deer are similar to those of sheep, goats, and cattle, the majority of the forages studied here would meet minimal animal requirements during years of adequate moisture.

Calcium requirements for white-tailed deer vary from 0.2 to $0.6 \%$, depending on the availability of $P$ (Ullrey et al. 1973), whereas cattle requiements vary from 0.16 to $0.58 \%$ depending on reproductive condition (NRC 1984). Based upon these levels, Ca concentration in all the forages studied were well above minimum requirements. Perhaps of more importance than actual $\mathrm{Ca}$ levels is the $\mathrm{Ca}: \mathrm{P}$ ratio. A 2:1 ratio of $\mathrm{Ca}: \mathrm{P}$ is best for optimum utilization and metabolism of both elements although higher ratios are acceptable if adequate vitamin $D$ is available. Ruminants grazing south Texas range lands should have ample vitamin $D$. The grass species studied here were well within acceptable $\mathrm{Ca}: \mathrm{P}$ ratio ranges, but most food habits studies indicate grasses comprise a small percentage $(<8 \%)$ of deer diets in south Texas. Browse and forbs are the most heavily utilized forages in south Texas deer diets and our data indicate these plants exhibited widely varying $\mathrm{Ca}: \mathrm{P}$ ratios ranging from near optimum in several forb species to 30:1 in Porlieria angustifolia, a species browsed heavily during the winter.

Sodium is the mineral most commonly deficient in northern ecosystems and the only nutrient for which herbivores appear to develop a highly specific appetite (Weeks and Kirkpatrick 1976, Staaland et al. 1980). Herbivores inhabiting dry subtropical habitats should not be Na stressed because moderate amounts of precipitation that occur in these regions do not leach available sodium (Robbins 1983). Our data indicate Na levels were well above the 0.06 to $0.10 \%$ Na required for beef cattle, sheep, and goats (NRC 1984). Sodium could become a problem during the summer when deer shift to a predominantly browse diet because many south Texas browse species contain condensed tannins which may reduce $\mathrm{Na}$ absorption and retention (Freeland et al. 1984, Barnes 1988). Sodium deficiencies can be easily solved by supplementation, a common practice on south Texas ranches.

Potassium and $\mathrm{Mg}$ requirements for deer are unknown. Cattle require between 0.5 and $0.7 \% \mathrm{~K}$, and between 0.05 and $0.25 \% \mathrm{Mg}$ for normal growth and development (NRC 1984). Based on these standards, neither mineral appears to be deficient in any of the forages. Magnesium becomes a problem most frequently when cattle are just entering lactation and placed on pastures containing less than $0.2 \% \mathrm{Mg}$. The high concentrations of $\mathrm{K}$ (up to 10 times the required levels) may complicate $\mathrm{Na}$ retention and absorption and has been shown to cause deer to increase $\mathrm{Na}$ consumption by visiting salt licks (Weeks and Kirkpatrick 1976).

Trace mineral requirements for deer and wildlife in general are virtually unknown. Cattle $\mathrm{Fe}$ requirements vary from 50 to 100 ppm depending on form of the $\mathrm{Fe}$, while $\mathrm{Mn}$ requirements vary from 20 to $40 \mathrm{ppm}$ (NRC 1984). The majority of forages examined contained adequate amounts of these 2 minerals except the fruits of Acacia berlandieri, A. tortuosa, and Prosopis glandulosa; the last of these constitutes a major portion of summer deer diets. Leaves of most browse species were well above required levels, compensating for the lower levels in fruits, but also contained substantial concentrations of tannins (Barnes 1988), which can decrease $\mathrm{Fe}$ absorption (Roy and Mukherjee 1979). Cattle require between 4 and $10 \mathrm{ppm} \mathrm{Cu}$ in the diet and between 20 and $40 \mathrm{ppm} \mathrm{Zn}$ for maintenance (NRC 1984). Most of the plant species examined meet or exceed these concentrations. However, cattle requirements may not be appropriate for deer (Greene, personal communication).

The variation among forage classes and species in mineral content have strong implications for potential diet selection in whitetailed deer. For example, prickly pear contained high levels of $\mathbf{K}$, $\mathrm{Mg}, \mathrm{Zn}$, and $\mathrm{Mn}$ during all seasons and can be a prominent component (up to $61 \%$ occurrence in the diet during the fall and winter) in deer diets in south Texas (Everitt and Gonzalez 1979). Likewise, species in the browse and forb groups containing high $\mathbf{P}$ (Ambrosia philostachya, Gaillardia pulchella, Clematis drummondii, and Cercidium texunum) or K (Physalis viscosa), may also be highly selected when present in the environment (Chamrad and Box 1968, Kie et al. 1980).

\section{Conclusions and Management Implications}

Nutritional data on the 52 deer forages collected from the Chaparral area indicate that, during years of adequate moisture and mild winter temperatures, plant macro and trace mineral concentrations, with the exception of $P$, meet or exceed animal requirements. The data indicate forbs provided adequate levels of $P$ during the spring and winter and marginal levels during the summer and fall. Browse is only a marginal source of $P$ during the spring, whereas grasses provide adequate $P$ during the spring and summer. Other studies have identified more critical $P$ deficiencies and have recommended supplementation (Everitt and Gonzalez 1981, Meyer and Brown 1985).

Managers should practice management techniques which provide a diversity of plant species, allowing deer the opportunity to select the highest quality diet available. Common brush management techniques such as creating a vegetational mosaic using rootplowing, shredding, or application of herbicides will open the canopy. This would allow an increase in forb diversity and density, with its associated increased nutritional value, and at the same time, leave dense sections of browse for shading, bedding, or escape cover and a standby forage source. Domestic livestock numbers should be monitored closely on these areas to provide deer the opportunity to utilize the increased forb crop.

\section{Literature Cited}

Arnold, L.A., Jr., and D.L. Drawe. 1979. Seasonal food habits of whitetailed deer in the South Texas Plains. J. Range Manage. 32:175-178.

Barnes, T.G. 1988. Digestion dynamics in white-tailed deer. Ph.D. Thesis, Texas A\&M Univ., College Station.

Chamrad, A.D., and T.W. Box. 1968. Food habits of white-tailed deer in south Texas. J. Range Manage. 21:158-164.

Everitt, J.H. 1972. Spring food habits of white-tailed (Odocoileus virginianus Bod) on the Zachry Ranch in south Texas. MS Thesis, Texas A\&I Univ., Kingsville.

Everitt, J.H., and C.L. Gonzalez. 1979. Botanical composition and nutrient content of fall and early winter diets of white-tailed deer in south Texas. Southwest. Natur. 24:297-310.

Everitt, J.H., and C.L. Gonzalez. 1981. Seasonal nutrient content in food plants of white-tailed deer on the South Texas Plains. J. Range Manage. 34:506-510.

Fisher, F.L. 1974. Native nutrient status of Texas soils. Texas Agr. Ext. Serv. Misc. Pub. L-1054. 
Freeland, W.J., P.H. Calcott, and D.P. Geiss. 1985. Allelochemicals, minerals and herbivore population size. Biochem. Sys. and Ecol. 13:195-206.

Greene, L.W., W.E. Pinchak, and R.K. Heitschmidt. 1987. Seasonal dynamics of minerals in forages at the Texas experimental ranch. J. Range Manage. 40:502-506.

Huston, J.E., B.S. Rector, L.B. Merrill, and B.S. Engdall. 1981. Nutritive value of range plants in the Edwards Plateau region of Texas. Texas Agr. Exp. Sta. Bull. 1357.

Inglis, J.M., B.A. Brown, C.A. McMahan, and R.E. Hood. 1986. Deerbrush relationships on the Rio Grande Plain, Texas. Texas Agr. Exp. Sta. Pub. 2M-7-86.

Jones, R.L., and H.P. Weeks, Jr. 1985. Ca, Mg, and $\mathrm{P}$ in the annual diet of deer in south-central Indiana. J. Wildl. Manage. 49:129-133.

Kallner, A. 1975. Determination of phosphate in serum and urine by a single step malachite green method. Clinica Chim. Acta. 59:35-39.

Kie, J.G., D.L. Drawe, and G. Scott. 1980. Changes in diet and nutrition with increased herd size in Texas white-tailed deer. J. Range Manage. 33:28-34.

Krausman, P.R., and J.A. Bissonette. 1977. Bone-chewing behavior of desert mule deer. Southw. Natur. 22:149-150.

Lynch, G.W. 1977. Nutritive value of forage species in the Rio Grande Plain Texas for white-tailed deer (Odocoileus virginianus) and domestic livestock. M.S. Thesis, Texas A\&M University, College Station.

Magruder, N.D., C.E. French, L.C. McEwen, and R.W. Swift. 1957. Nutritional requirements of white-tailed deer for growth and antler development. II. Experimental results of the third year. Pa. Agr. Exp. Sta. Bull. 628.

McEwen, L.C., C.E. French, N.D. Magruder, R.W. Swift, and R.H. Ingram. 1957. Nutritional requirements of the white-tailed deer. Trans. North Amer. Wildl. and Natur. Resour. Conf. 22:119-132.

Meyer, M.W., and R.D. Brown. 1985. Seasonal trends in the chemical composition of ten range plants in south Texas. J. Range Manage. 38:154-157.

National Research Council. 1984. Nutrient requirements of beef cattle (6th ed.). National Academy Press, Washington, D.C.

Nuwanyakpa, M.Y., K.K. Bolsen, G.L. Posler, M.Q. Diaz, and F.R. Rivera. 1983. Nutritive value of seven tropical weed species during the dry season. Agron. J. 75:566-569.

Poppi, D.P., D.J. Minson, and J.H. Ternout. 1981. Studies of cattle and sheep eating leaf and stem fractions of grasses. I. The voluntary intake digestibility, and retention time in the reticulo-rumen. Aust. J. Agr. Res. 32:99-108.
Robbins, C.T. 1983. Wildlife feeding and nutrition. Academic Press, New York, N.Y.

Roy, S.H., and S. Mukherjee. 1979. Influence of food tannins on certain aspects of iron metabolism: Part I-Absorption and excretion in normal and anemic rats. Indian J. Biochem. and Physics 16:93-98.

Shafer, E.L. 1963. The twig-count method for measuring hardwood deer browse. J. Wildl. Manage. 27:428-438.

Staaland, H., R.G. White, J.R. Luick, and D.F. Holleman. 1980. Dietary influences on sodium and potassium metabolism of reindeer. Can. J. Zool. 58:1728-1734.

Staaland, H., I. Brattbak, K. Ekern, and K. Kildemo. 1983. Chemical composition of reindeer forage plants in Svalbard and Norway. Holarctic Ecol. 6:109-122.

Stephson, D.C., and R.D. Brown. 1984. Calcium kinetics in male whitetailed deer. J. Nutr. 114:1014-1024.

Stuth, J.W., J.R. Brown, P.D. Olson, M.R. Araujo, and H.D. Algoe. 1986. Effects of stocking rate on critical plant animal interations in a rotationally grazed Schizicarium paspalum savanna. In: F.P. Horn, J. Hodgson, J.J. Mott, and R.W. Broughman (eds.). Critical plant-animal interaction. Winrock Internat. Publ. Ser.

Ulrey, D.E., W.G. Youatt, H.E. Johnson, L.D. Fay, B.L. Schoepke, W.T. Magee, and K.K. Keahey. 1973. Calcium requirements of weaned whitetailed deer fawns. J. Wildl. Manage. 37:187-194.

Ullrey, D.E., W.G. Youatt, H.E. Johnson, A.B. Cowan, L.D. Fay, R.L. Covert, W.T. Magee, and K.K. Keahey. 1975. Phosphorus requirements of weaned white-tailed deer fawns. J. Wildl. Manage. 39:590-595.

USDA. 1976. Soil Survey of Uvalde County, Texas. Soil Conserv. Serv.

Varner, L.W., L.H. Blankenship, and G.W. Lynch. 1977. Seasonal changes in nutritive value of deer food plants in south Texas. Proc. Annu. Conf. Southeast. Assoc. Fish and Wildl. Agen. 31:99-106.

Varner, L.W., and L.H. Blankenship. 1987. Southern Texas shrubsnutritive value and utilization by herbivores. In: F.D. Provenza, J.T. Flinders, and E.D. McArthur (eds.) Proc.-Symp. Plant-Herbivore Interactions. USDA Forest Serv. Gen. Tech. Rep. INT-222.

Weeks, H.P., Jr., and C.M. Kirkpatrick. 1976. Adaptations of white-tailed deer to naturally occuring sodium deficiencies. J. Wildl. Manage. 40:610-625. 